\title{
Effects of land use types on selected soil physical and chemical properties: The case of Kuyu District, Ethiopia
}

\author{
Mulugeta Tufa ${ }^{a}, *$, Asmare Melese ${ }^{b}$, Wondwosen Tena ${ }^{b}$ \\ a Department of Natural Resource Management, College of Agriculture and Natural Resource, Mekdela Amba University, \\ Tulu Awuliya, Ethiopia \\ b Department of Plant Science, College of Agriculture and Natural Resource Sciences, Debre Berhan University, \\ Debre Berhan, Ethiopia
}

\section{Article Info}

Received : 18.05 .2018

Accepted : 03.01.2019

\begin{abstract}
Information about effects of land use types on selected soil physical and chemical properties is essential in sustainable utilization of soil resources. Therefore, this study was conducted to evaluate effects of land use types on selected soil physical and chemical properties on Kuyu district, Ethiopia. Totally, 24 composite soil samples were collected from grass, cultivated, forest and grazing lands by two soil depths $(0-20 \mathrm{~cm}$ and $20-40 \mathrm{~cm})$ with three replications. The two way analysis of variance was used to test the mean differences of the soil physical and chemical properties. The highest mean values of sand and clay were recorded in cultivated and grasslands, respectively. The mean bulk density of the soils ranged from 1.10 and $1.37 \mathrm{~g} \mathrm{~cm}^{-3}$ and the mean total porosity ranged from 48.2 to $58.7 \%$, which indicated the less soil compaction. The $\mathrm{pH}$ ranged from 7.68 to 8.00 while the mean values of $\mathrm{OM}$ ranged from 3.15 to $5.02 \%$. However, the mean values of total $\mathrm{N}$ ranged from 0.18 to $0.26 \%$. The mean value of available $\mathrm{P}$ ranged from 1.26 to $5.37 \mathrm{mg} \mathrm{kg}^{-1}$, which implies that high deficiency of available $P$ in the study area. The exchangeable basic cations and CEC values were within high to very high ranges in all land use types. Conversion of land use types from one to another has adverse effects on soil properties, especially overgrazing and cultivation of deforested land. Therefore, the proper soil and water conservation practice are important in the study area to enhance soil fertility and crop productivity.

Keywords: Cultivated land, forest land, grazing land, soil depth, soil fertility.
\end{abstract}

(C) 2019 Federation of Eurasian Soil Science Societies. All rights reserved

\section{Introduction}

Land use is defined as the arrangements, activities and inputs people undertake in a certain land cover type to produce, change or maintain it (Ufot et al., 2016). Successful agriculture requires the sustainable use of soil resource, because soil can easily lose its quality and quantity within a short period of time for different reasons such as intensive cultivation, leaching and soil erosion (Kiflu and Beyene, 2013). Agricultural practice, therefore, requires basic knowledge of sustainable use of the land (Takele et al., 2014). A success in soil management to maintain the soil quality depends on the understanding of how the soil responds to agricultural practices over time (Duguma et al., 2010). However, the basis of this sustainable agricultural development is good quality of the soil, since maintenance of soil quality is an integral part of sustainable agriculture and the convenient witness to enhance the crop productivities (Liu et al., 2010). Soil resource has also provided a great contribution in the production of food and fiber, in the maintenance of local, regional, and worldwide environmental quality (Bore and Bedadi, 2015).

On the other hand, the ever-increasing human population is most challenging in areas like central Ethiopia, where there is a very high population density and heavy dependence on land resources. This is the atrocious threat in, which soil properties are adversely damaged thereby leads to land degradation and hampered the sustainability of soil resources (Yimer and Abdulkadir, 2011). The major causes of land degradation, natural

\footnotetext{
${ }^{*}$ Corresponding author.

Department of Natural Resource Management, College of Agriculture and Natural Resource, Mekdela Amba University, P.0. Box 32, Tulu Awuliya, Ethiopia

Tel.: +251916892194

E-mail address: ejersa2008@gmail.com

e-ISSN: $2147-4249$ DOI: $10.18393 /$ ejss.510744
} 
resources depletion and environmental deterioration in Ethiopia are: cultivation on steep soil with inadequate management in soil conservation or vegetation cover, erratic and torrential rainfall patterns, deforestation and overgrazing (Aytenew and Kibret, 2016). In addition, the topography of the land has also a great impact on the soil quality and soil depth due to the interaction impact of cultivation practices and slope (Pavlu et al., 2007). Therefore, reducing resource degradation, increasing agricultural productivity, reducing poverty, and achieving food security are major challenges of the countries in tropical Africa (Qadir et al., 2014). Thus, possible effort should be focused on the maintenance of the physical, biological and socio-economic environment for production of food crops, livestock, wood and other products through sustainable use of natural resources (Adeyemo and Agele, 2010).

With the increment of human and livestock population, temporary intensively expansion of farmland and grazing areas has begun to influence the soil properties (Mustapha, 2007). This resulted, as the expansion of land use conversion is based on the conversion of the existing forest lands into cultivated lands and grazing lands (Chemada et al., 2017). However, when the intensification limit is reached, for example, in countries like Ethiopia, where the forest land area dropped from $40 \%$ to below 3\% of the land cover and the human population is rapidly growing (MOFED, 2007) (almost doubling every 26 years), intensification i.e. the frequent and continuous utilization of the available land has continued. However, the current studies indicated that the forest coverage area is becoming $15 \%$ by afforestation and plantation systems (FAO, 1998). Various studies have been conducted to assess the effect of land use types on soil physical and chemical properties in Ethiopia (Lemenih et al., 2005; Lemma et al., 2006; Yimer et al., 2008). Lemma et al. (2006) showed that afforestation of farmland with various trees specious increased total nitrogen $(\mathrm{N})$, exchangeable potassium (K), and exchangeable calcium (Ca) on the surface soil layer than subsurface soil layer. Yimer et al. (2008) also compared croplands, forest lands and grazing lands and found that soil organic carbon (OC) and total $\mathrm{N}$ decreased in croplands as compared to forest lands. He also suggested that the OC was abundant of surface soil layer compared to the lower soil horizon.

Currently, the forest land was drastically degraded in the study area because of the timber production, firewood, expansion of cultivated and grazing lands, which may results in the decline of soil fertility and limit crop productivity, which in turns affect the livelihood of local communities. Additionally, the grassland has been converted into grazing lands in the study area. This is because of the increment of livestock, which leads to soil compaction by removing the palatable shrubs and bush trees, and expose the surface soil for the erosion problems. In order to put the proper recommendations for sustainable utilizations of soil resources and improve crop productivity, the information about effects of land use types on soil physical and chemical properties are essential. Therefore, the objective of this study was to evaluate effects of land use types on selected soil physical and chemical properties on Jila Kerensa kebele, Kuyu district.

\section{Material and Methods}

\section{Description of the study area}

The study was conducted on Jila Kerensa kebele, Kuyu district, north Shewa zone, Oromia National Regional State, Ethiopia. It's located on the $150 \mathrm{~km}$ in north direction from Addis Ababa. Geographically, it is located at about $9^{\circ} 6^{\prime} 34^{\prime \prime} \mathrm{N}$ latitude and $38^{\circ} 05^{\prime} 00^{\prime \prime} \mathrm{E}$ longitude with an altitudinal range of 1200-2600 meters above sea level (masl) (KWAO, 2017).

\section{Climate}

The vast majority part of the study area is badda daree (woinadega) (1500-2500 masl) which accounts $75 \%$, followed by gammoojjii (kolla) (below 1500 masl) (20\%). The rest 5\% of the area is constituted by baddaa (dega) (above 2500 masl) agro-climatic zone. The average annual rainfall of the study area was $1475.3 \mathrm{~mm}$ per year, where the maximum is obtained during summer (kremt) season from June to September and the minimum is obtained during spring (belg) season from March to June. The mean monthly minimum and mean maximum air temperature of the study area were 8.0 and $20.0^{\circ} \mathrm{C}$, respectively (KWAO, 2017).

\section{Soils, geology and topography}

According to FAO/UNDP (1984), the dominant soil type of the study area is Vertisols. Its vernacular or local name is "Biyyee Gurraacha" meaning black soil and clay is the dominant soil texture. According to (KWAO, 2017), the most soils of the study area have been weathered from basaltic bedrock formed during the tertiary era. The geology or parent material of the soil the study area is alluvial and colluvial which deposits and derived from the basaltic rocks. The topography of the study area is plain with the flat slopes (64\%), undulating slopes $(21 \%)$ and valleys parts which covered $(15 \%)$. Most $(90 \%)$ of study areas are in ranges of $0-10 \%$ slope level and the remaining area is more than this slope (KWAO, 2017). 


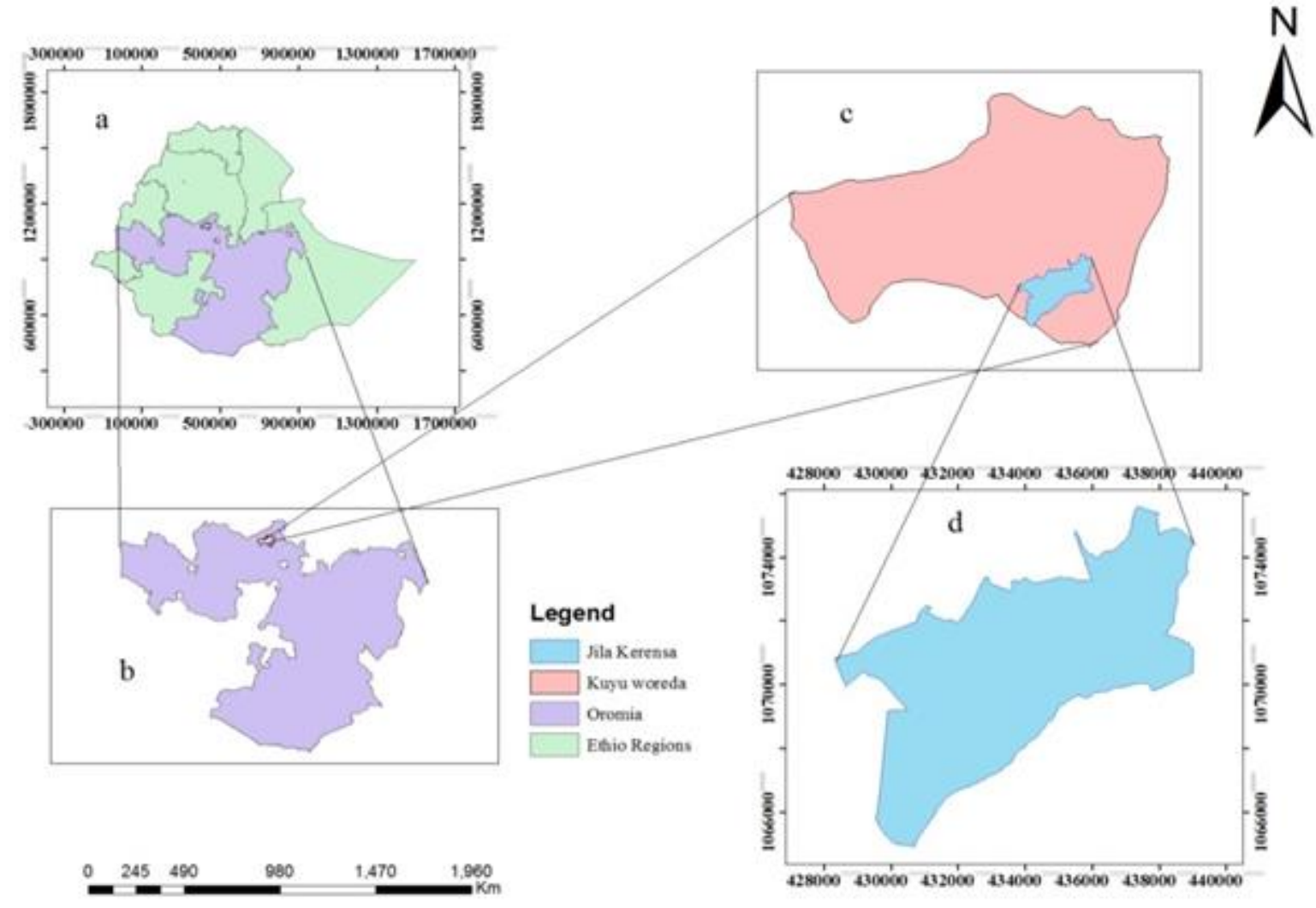

Figure 1. Location map of the study area: (a) Map of Ethiopia showing Oromia Regional State, (b) Oromia Regional State showing Kuyu woreda, (c) Kuyu woreda and (d) Jila Kerensa kebele.

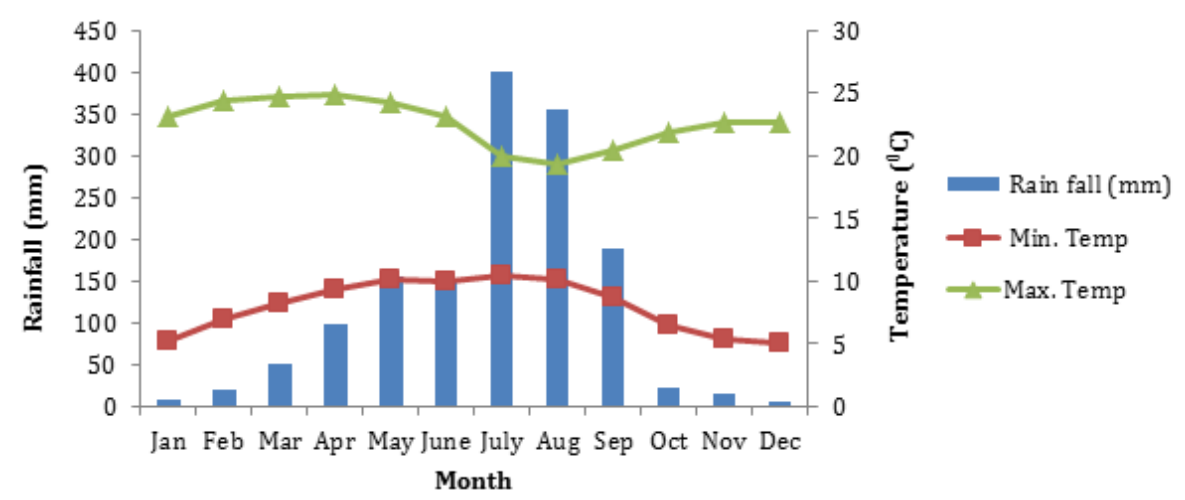

Figure 2. Mean monthly rainfall and mean monthly minimum and maximum temperatures of the study area for eight years (2010-2017)

\section{Vegetation}

According to KWAO (2017), the study area has the scarcity of natural forest in different land use types. However, plantation forests such as eucalyptus trees are found in dega and woinadega regions of the study area. As it is true for most areas of Ethiopia deforestation has been one of the serious problems in the study area. Vegetation has been cleared for the purpose of timber production, firewood, construction materials and for expansion of cultivation lands. As a result, the fertile soils have been lost and the wild animals have been endangered. Almost all flat land of the study area has small form of natural vegetation, whereas the valleys and sloppy lands are covered with scattered bushes and shrubs (KWAO, 2017).

The study area contained both native and exotic plant species. There are the several diversity of native plant species such as, Birbirsa (Zigba) (Podocarpus talacta), Waddeessa (Wanza) (Cordia africana), Ejersa (Weira) (Olean africana), Sombo (Ekebcrgia capensis) and Laaftoo (girar) (Acacia's) species are commonly found in most parts of the study area. Additionally, there are some exotic species such as Gravillia, Juniperusprocera and Eucalyptus species. Eucalyptus species such as globulus and camaldulensis are the major species planted in the study area. Gravillia species are only planted and found around the homestead area while Juniperusprocera are sparsely found in large areas (KWAO, 2017). 


\section{Land use and farming system}

According to KWAO (2017), in the study area there are different land use types: cultivated lands, forest lands, bush and shrubs, grasslands, and grazing lands. The total land coverage areas of Jila Kerensa kebele is 4973.341 ha, where cultivated land is (3673.077 ha), grazing land (362.46 ha), grassland (308.23 ha), forest land (274.68 ha), settlement (228.059 ha), bush and shrubs (114.84 ha), institution (6.275 ha) and urban area was (5.72 ha) (KWAO, 2017).

The agricultural activities of the study area is mixed farming system that is sowing and producing a variety of crops as well as rearing animals that improve the livelihoods of local communities and their income. All crops are annual and rain feed crops, such as teff (Eragrostis tef), maize (Zea mays L.), wheat (Triticum spp), sorghum (Sorghum bicolor), barley (Hordeum spp), chickpea (Cicer arietinum), grass pea (Lathyrus sativus), lentil (Lens culinaris), bean (Fabaceae spp), pea (Pisum sativum), niger seed (Guizotia abyssinica), linseed (Linus usitatissiumum), and sunflower (Helianthus annus) are the common one. From the fruit, sugar cane (Saccharum officinarum L.), banana (Musa spp.) and orange (Citrus aurantium) are found in some specific study area of the small scale level. The livestock of study area includes cattle, sheep, goats and equine (donkeys, mules and horses) (KWAO, 2017).

\section{Site Selection}

For this study, Jila Kerensa kebele was purposively selected from Kuyu district because higher land degradation and soil erosion problems are commonly observed in this area which has a deleterious impact on soil physical and chemical properties under different land use types. Prior to the collection of soil samples, discussions was made with the woreda agricultural office expertise in order to get the prehistory and current information about the utilization of land use types and lifestyle of the local community in the study area.

Thenafter, a reconnaissance field survey was carried out in order to have a general view of land use types in the study area. Throughout the visual observation of the study area its geographic coordination (latitudes and longitudes) and elevation were recorded by global positioning system (GPS). Thenafter, for addressing the intended objective, the treatments were stratified in to four land use types viz: cultivated, grazing, forest and grasslands.

\section{Soil Sampling}

Composite soil samples were collected from the four land use types (cultivated, grazing, forest and grasslands) by two soil depths $(0-20 \mathrm{~cm}$ and $20-40 \mathrm{~cm})$ with three replications. The whole factors were situated on the same slope, geologic and topography. Both undisturbed and disturbed soil samples were taken from two soil depths from ten to fifteen sampling point based on the heterogeneity of land unit in a zigzag manner. Undisturbed soil samples were taken by core sampler to measure the soil bulk density, whereas the disturbed soil samples were taken by using an auger to measure the rest selected soil physical and chemical properties.

During the collection of soil samples, gravel materials, dead plants, old manures, areas near trees and compost pits were excluded. This is to minimize the differences variation, which may arise because of the dilution of soil OM due to mixing through cultivation and other factors. After these materials and areas were separated, 24 composite soil samples were collected from representative land use types. Thenafter, about one kilogram of the soil samples from 24 composite soil samples were sub-sampled and packed by plastic bags. After the composite soil sub-samples were taken and packed, it was air dried and finally ground and sieved by $2 \mathrm{~mm}$ sieve to the analysis of physical and chemical properties of soil. However, organic carbon $(\mathrm{OC})$ and total nitrogen $(\mathrm{N})$ analyses were ground to pass $0.5 \mathrm{~mm}$ size sieve and then brought to the laboratory for the analysis of selected soil physical and chemical properties.

\section{Analysis of soil physical and chemical properties}

Soil texture was analyzed by the Bouyoucous hydrometer method (Bouyoucous, 1962), after OM was destroyed or burned by using hydrogen peroxide $\left(\mathrm{H}_{2} \mathrm{O}_{2}\right)$, soil particles dispersed and disintegrated by sodium carbonate $\left(\mathrm{Na}_{2} \mathrm{CO}_{3}\right)$ and sodium hexametaphosphate $\left(\mathrm{NaPO}_{3}\right)$ in distilled water and finally using amyl alcohol to destroy the soil solution foam. After the particle size distributions were determined in percent, the textural class of the soil could obtained by using USDA soil textural triangle classification system (USDA, 2008).

The bulk density (BD) of the soil was measured from undisturbed soil samples collected using a core sampler after drying the core samples in an oven at $105^{\circ} \mathrm{C}$ (Black, 1965). The total porosity of soil samples 
was estimated from the values of bulk density (BD) and particle density (PD) (assuming an average particle density of mineral soil is $2.65 \mathrm{~g} \mathrm{~cm}^{-3}$ ). Then the total porosity (TP) was calculated as,

$\mathrm{TP}(\%)=(1-$ Bulk density/Particle density $) *(100)$.

The $\mathrm{pH}$ of the soils was measured in water $\left(\mathrm{H}_{2} \mathrm{O}\right)$ suspension in a 1:2.5 (soil: liquid) by pH meter, whereas electrical conductivity was measured by a conductivity meter (Van Reeuwijk, 1992). Calcium carbonate content of the soil was determined by an acid neutralization method in, which the soil carbonate was neutralize by standard $0.1 \mathrm{M} \mathrm{HCl}$ solution and back titrated with standard $\mathrm{NaOH}$ (Van Reeuwijk, 1992).

To determine organic carbon, the Walkley and Black (1934) method was used in which the carbon was oxidized under standard conditions with potassium dichromate $\left(\mathrm{K}_{2} \mathrm{Cr}_{2} \mathrm{O}_{7}\right)$ in sulfuric acid solution. Finally, the organic matter content of the soil was calculated by multiplying the organic carbon percentage by 1.724 following the assumptions that $\mathrm{OM}$ is composed of $58 \%$ carbon. The total nitrogen content in soils was determined using the Kjeldahl digestion, distillation and titration method by oxidizing the OM in concentrated sulfuric acid solution $\left(0.1 \mathrm{~N} \mathrm{H}_{2} \mathrm{SO}_{4}\right)$ as described by Black (1965). Thenafter, C:N was calculated by dividing organic carbon to total nitrogen. The available $\mathrm{P}$ was calculated by the Olsen method using sodium bicarbonate $\left(0.5 \mathrm{MNaHCO}_{3}\right)$ as an extraction solution (Olsen et al., 1954).

Exchangeable bases ( $\mathrm{Na}, \mathrm{K}, \mathrm{Mg}$ and $\mathrm{Ca}$ ) were determined after extracting the soil samples by ammonium acetate $\left(1 \mathrm{~N} \mathrm{NH}_{4} \mathrm{OAc}\right)$ at $\mathrm{pH} 7.0$. Exchangeable $\mathrm{Na}$ and $\mathrm{K}$ were analyzed by flame photometer while $\mathrm{Ca}$ and $\mathrm{Mg}$ in the extracts were analyzed using atomic absorption spectrophotometer (AAS) as described by Rowell (1994). Cation exchange capacity was estimated titrimetrically by distillation of ammonium that could be displaced by sodium from $\mathrm{NaCl}$ solution (Chapman, 1965). Percent base saturation was calculated by dividing the sum of the charge equivalents of the base forming cations ( $\mathrm{Na}, \mathrm{K}, \mathrm{Mg}$ and $\mathrm{Ca}$ ) by the CEC of the soil and multiplying by 100 .

\section{Statistical Analysis}

The two way analysis of variance (ANOVA) was used to test differences in soil physical and chemical properties across land use types and soil depths. For statistically different parameters at probability $5 \%$ ( $\mathrm{p} \leq$ 0.05), means were separated by the Duncan's Multiple Range Test (DMRT) using SAS software version 9.4 (SAS, 2013).

\section{Results and Discussion}

\section{Selected soil physical properties under different land use types Soil texture}

According to the results of analysis of variance (ANOVA) revealed that there was no significant different on the sand particle under land use types, soil depths and in the interaction of the land use types with the soil depth. But, silt and clay particles were significantly $(\mathrm{P} \leq 0.05)$ affected by land use types (Tables 1 and 2$)$. Although there was no statistical disparity on soil sand particles amongst land use types, there was the numerical variation across the land use types.

Table 1. Interaction effects of land use types and soil depth on selected soil physical properties on Jila Kerensa kebele

\begin{tabular}{|c|c|c|c|c|c|c|c|c|c|c|}
\hline \multirow[b]{3}{*}{ Land use types } & \multirow{2}{*}{\multicolumn{2}{|c|}{$\begin{array}{l}\text { Sand (\%) } \\
\text { Soil depth (cm) }\end{array}$}} & \multirow{2}{*}{\multicolumn{2}{|c|}{$\begin{array}{l}\text { Silt (\%) } \\
\text { Soil depth (cm) }\end{array}$}} & \multirow{2}{*}{\multicolumn{2}{|c|}{$\begin{array}{l}\text { Clay (\%) } \\
\text { Soil depth (cm) }\end{array}$}} & \multirow{2}{*}{\multicolumn{2}{|c|}{$\frac{\text { BD }\left(\mathrm{g} \mathrm{cm}^{-3}\right)}{\text { Soil depth }(\mathrm{cm})}$}} & \multirow{2}{*}{\multicolumn{2}{|c|}{$\begin{array}{l}\text { TP }(\%) \\
\text { Soil depth }(\mathrm{cm})\end{array}$}} \\
\hline & & & & & & & & & & \\
\hline & $0-20$ & $20-40$ & $0-20$ & $20-40$ & $0-20$ & $20-40$ & $0-20$ & $20-40$ & $0-20$ & $20-40$ \\
\hline Grass & 25.0 & 24.7 & 26.0 & $25.0^{\mathrm{b}}$ & 49.0 & $50.3^{a}$ & $1.09^{c}$ & $1.1^{\mathrm{d}}$ & $58.8^{a}$ & $58.5^{a}$ \\
\hline Cultivated & 34.3 & 26.3 & 26.7 & $22.7^{b}$ & 39.1 & $51.0^{\mathrm{a}}$ & $1.38^{\mathrm{a}}$ & $1.36^{\mathrm{a}}$ & $47.8^{c}$ & $48.56^{d}$ \\
\hline Forest & 21.3 & 25.3 & 32.7 & $38.0^{\mathrm{a}}$ & 46.0 & $36.7^{b}$ & $1.15^{b}$ & $1.16^{c}$ & $56.5^{b}$ & $55.9^{\mathrm{b}}$ \\
\hline Grazing & 27.7 & 25.0 & 28.7 & $30.7^{\mathrm{ab}}$ & 43.7 & $44.3^{\mathrm{ab}}$ & $1.39^{a}$ & $1.34 \mathrm{~b}$ & $47.6^{c}$ & $49.4^{c}$ \\
\hline CV (\%) & 19.62 & 18.24 & 20.55 & 16.05 & 17.05 & 12.51 & 0.64 & 0.67 & 0.61 & 0.55 \\
\hline p-values & ns & ns & ns & $*$ & ns & $*$ & $* * *$ & $* * *$ & $* * *$ & $* * *$ \\
\hline
\end{tabular}

Interaction means within a columns followed by the different letter(s) are significantly different from each other at $\mathrm{P} \leq 0.05$; $\mathrm{ns}=\mathrm{not}$ significant; $^{*}=$ significant at $\mathrm{P} \leq 0.05 ;{ }^{* *}=$ significant at $\mathrm{P} \leq 0.001 ; \mathrm{BD}=$ Bulk density; $\mathrm{TP}=$ Total porosity; $\mathrm{CV}=\mathrm{Coefficient}$ of variation.

Considering the interaction of land use types with soil depth, the highest (34.3\%) and the lowest (21.3\%) value of sand was found on the surface $(0-20 \mathrm{~cm})$ soil layer of cultivated and forest lands, respectively. Whereas the highest (51.0\%) and lowest (36.7\%) values of clay content were found in the subsurface $(20-40$ $\mathrm{cm}$ ) soil layer of the cultivated and forest lands, respectively (Table 1). In the case of soil depth, the higher sand content was obtained at the surface $(0-20 \mathrm{~cm})$ soil layer, whereas the higher silt and clay were recorded in the subsurface $(20-40 \mathrm{~cm})$ of soil layer (Table 2). Generally, the clay content was higher in the 
subsurface layer of cultivated land as compared to the adjacent forest, grass and grazing lands. The reason might be due to the preferential removal of clay particles and its downward movement into the subsurface soil layer through the process of clay migration.

Similarly, Chemada et al. (2017) stated that the clay content of cultivated land was increased from the surface to subsurface soil layer due to the long period of cultivation. Additionally, Gebrelibanos and Assen (2013) reported that lower clay and higher sand content was found in the surface layer and higher clay contents was found in the subsurface layer of cultivated land than the others adjacent natural forest, plantation forest and grazing lands. Generally, the variation of soil texture amongst land use types is implies that the effects of land use types on soil propertie which triggered from different utilization and management system of land use types (Abbasi et al., 2007).

Table 2. Main effect of land use types and soil depth on selected physical properties of soil on Jila Kerensa kebele

\begin{tabular}{|c|c|c|c|c|c|}
\hline Treatments & Sand (\%) & Silt (\%) & Clay (\%) & $\mathrm{BD}\left(\mathrm{g} \mathrm{cm}^{-3}\right)$ & TP (\%) \\
\hline & & & \multicolumn{3}{|c|}{ Land use types } \\
\hline Grass & 23.30 & $25.33^{b}$ & $51.33^{a}$ & $1.10^{\mathrm{d}}$ & $58.70^{\mathrm{a}}$ \\
\hline Cultivated & 30.30 & $24.70^{\mathrm{b}}$ & $45.00^{\mathrm{ab}}$ & $1.37^{\mathrm{a}}$ & $48.20^{c}$ \\
\hline Forest & 23.30 & $35.33^{a}$ & $41.33^{b}$ & $1.16^{\mathrm{c}}$ & $56.20^{\mathrm{b}}$ \\
\hline \multirow[t]{2}{*}{ Grazing } & 26.30 & $29.70^{\mathrm{ab}}$ & $44.00^{\mathrm{ab}}$ & $1.36^{\mathrm{b}}$ & $48.50^{c}$ \\
\hline & & & \multicolumn{3}{|c|}{ Soil depth $(\mathrm{cm})$} \\
\hline $0-20$ & 27.60 & 28.50 & 43.92 & $1.25^{\mathrm{a}}$ & $52.70^{\mathrm{b}}$ \\
\hline $20-40$ & 24.10 & 29.00 & 46.90 & $1.24^{\mathrm{b}}$ & $53.11^{\mathrm{a}}$ \\
\hline Land use & ns & $*$ & $*$ & $* * *$ & $* * *$ \\
\hline Depth & ns & ns & ns & $* *$ & $* *$ \\
\hline Land use $*$ depth & ns & ns & ns & $* * *$ & $* * *$ \\
\hline CV $(\%)$ & 22.40 & 22.54 & 14.32 & 0.62 & 0.54 \\
\hline
\end{tabular}

Main effect means within a columns followed by the different letter(s) are significantly different from each other at $\mathrm{P} \leq 0.05$; $\mathrm{ns}=\mathrm{not}$ significant; ${ }^{*}=$ significant at $\mathrm{P} \leq 0.05 ;{ }^{* *}=$ significant at $\mathrm{P} \leq 0.01 ;{ }^{* * *}=$ significant at $\mathrm{P} \leq 0.001$.

\section{Bulk densities}

The soil bulk density value was significantly $(\mathrm{P} \leq 0.001)$ affected by land use and by their interaction effects, whereas it was significantly affected by soil depth at $\mathrm{P} \leq 0.01$ (Tables 1 and 2). Considering the main effects, the highest $\left(1.37 \mathrm{~g} \mathrm{~cm}^{-3}\right)$ mean value of bulk density was recorded on the cultivated land and the lowest (1.10 $\mathrm{g} \mathrm{cm}^{-3}$ ) mean value was found under the grassland (Table 2). The reason for the lowest soil bulk density of the grassland could be due to the higher clay content and less disturbance of the soil under grassland. The higher bulk density of soil in cultivated land might be due to the practice of ploughing in cultivated soil, which tends to lower the quantity of $\mathrm{OM}$ of that soil through animal trafficking and expose the soil surface to direct strike by rain drops. This finding is in agreement with Yitbarek et al. (2013) who found the highest bulk density under cultivated land compared to the adjacent grazing and forest lands at a soil depth of 0-20 cm. Additionally, Takele et al. (2014) and Abad et al. (2014) suggested that the bulk density of cultivated land was higher than that of adjacent grazing land and forest lands at soil depth of $0-30 \mathrm{~cm}$. Paradoxically, Lelisa and Abebaw (2016) found that the higher bulk density in the grassland compared to the adjacent bare land and rehabilitated land at a soil depth of $0-10 \mathrm{~cm}, 20-30 \mathrm{~cm}$ and $30-40 \mathrm{~cm}$. Generally, the ranges of bulk density values observed in this study are within the ranges expected value $\left(1.1\right.$ to $\left.1.4 \mathrm{~g} \mathrm{~cm}^{-3}\right)$ in most mineral soils as indicated by Gupta (2004). Since the bulk density of this study area was within the expected values the aeration and water movement within the soil structure is in conducive situation that attain plant growth and determine the numbers and diversity of soil microbes thereby they furnish the versatile function in agrarian activities.

The bulk density of the soil was insignificantly and negatively correlated with silt and clay particles values at $r=-0.13,-0.21$, respectively. But it was significantly and negatively $\left(r=-0.99^{* * *}\right)$ correlated with the total porosity (Table 8). This might be due to the reciprocal relationship between soil bulk density and total porosity, which shows the degree of soil compaction.

\section{Total porosity}

The result of the analysis of variance (ANOVA) showed that the total porosity of soil was significantly (P $\leq$ 0.001 ) affected by land use types and by their interaction. But it was significantly affected by soil depth at P $\leq$ 0.01 (Tables 1 and 2). Considering the interaction of land use types with soil depth, the highest (58.8\%) and the lowest (47.6\%) values of total porosity was recorded on the surface soil layer of grass and grazing lands, 
respectively (Table 1). The higher value of soil total porosity in grassland was implied that the low bulk density of grassland.

Regarding to the mean values of total porosity under different land use types, the mean total porosity of grass, cultivated, forest and grazing lands were 58.7, 48.2, 56.2 and 48.5\%, respectively (Table 2). In the case of both soil depths, the higher value of total porosity was recorded at the subsurface soil layer. The higher and lower of total porosity across the adjacent land use types was implies the lower and higher bulk density values of that soil, respectively.

The soil total porosity was insignificantly and positively correlated with soil OM and clay at $r=0.04$ and at $r$ $=0.22$, respectively. This is because of the soil contained $\mathrm{OM}$ and clay particles have meso or microspores, which has low soil aeration and water percolation. But it was significantly and positively correlated with $\mathrm{CaCO}_{3}$ and $\mathrm{CEC}$ of the soil at $\mathrm{r}=0.76^{* * *}$ and at $\mathrm{r}=0.75^{* * *}$, respectively (Table 8).

According to Landon (1991) the favorable total porosity of sand particles was about $40 \%$ whereas that of clay content soil is about $50 \%$ and above to sustain and regulate the activities of soil biota. Therefore, having this as departure the findings of this study is in agreement with these ideas and confirms no problems of soil properties via water infiltration and soil aeration under adjacent different land use types in the study area. Moreover, the high total porosity of the soil implies that the less problem of water logging and surface runoff.

\section{Selected soil chemical properties under different land use types}

\section{Soil reaction $(\mathrm{pH})$, electrical conductivity and calcium carbonate}

The analysis of variance results indicated that the soils $\mathrm{pH}-\mathrm{H}_{2} \mathrm{O}$ was not significantly affected by land use types, soil depth and their interaction (Tables 3 and 5). Even though there was no statistical variation of soil reaction under different land use types and in their interaction effects, there was a numerical variation on its values. Considering the interaction of land use types with soil depth, the highest (8.1) and the lowest (7.6) values of soil reaction were recorded on the surface $(0-20 \mathrm{~cm})$ soil layer of grass and cultivated lands, respectively (Table 3). The higher $\mathrm{pH}$ value was recorded at the surface soil layer than the subsurface soil layer (Table 5).

Table 3. Interaction effects of land use types and soil depth on soil pH, EC and $\mathrm{CaCO}_{3}$ on Jila Kerensa kebele

\begin{tabular}{|c|c|c|c|c|c|c|}
\hline \multirow[b]{3}{*}{ Land use types } & \multirow{2}{*}{\multicolumn{2}{|c|}{$\begin{array}{l}\mathrm{pH}-\mathrm{H}_{2} \mathrm{O}(1: 2.5) \\
\text { Soil depth }(\mathrm{cm})\end{array}$}} & \multirow{2}{*}{\multicolumn{2}{|c|}{$\frac{\mathrm{EC}\left(\mathrm{dS} \mathrm{m} \mathrm{m}^{-1}\right)}{\text { Soil depth }(\mathrm{cm})}$}} & \multicolumn{2}{|c|}{$\mathrm{CaCO}_{3}(\%)$} \\
\hline & & & & & & th $(\mathrm{cm})$ \\
\hline & $0-20$ & $20-40$ & $0-20$ & $20-40$ & $0-20$ & $20-40$ \\
\hline Grass & 8.1 & 7.9 & $0.32^{b}$ & $0.24^{\mathrm{b}}$ & $8.13^{b}$ & $9.13^{\mathrm{a}}$ \\
\hline Cultivated & 7.6 & 7.7 & $0.31^{b}$ & $0.33^{\mathrm{ab}}$ & $6.80^{c}$ & $7.20^{\mathrm{b}}$ \\
\hline Forest & 7.8 & 7.9 & $0.57^{\mathrm{a}}$ & $0.48^{a}$ & $11.50^{\mathrm{a}}$ & $9.06^{\mathrm{a}}$ \\
\hline Grazing & 7.7 & 7.7 & $0.30^{\mathrm{b}}$ & $0.35^{\mathrm{ab}}$ & $5.10^{\mathrm{d}}$ & $5.86^{c}$ \\
\hline $\mathrm{CV}(\%)$ & 4.24 & 4.82 & 20.53 & 25.24 & 5.44 & 4.36 \\
\hline $\mathrm{P}$ - values & ns & ns & $* *$ & $*$ & $* * *$ & $* * *$ \\
\hline
\end{tabular}

Interaction means within a columns followed by the different letter(s) are significantly different from each other at $\mathrm{P} \leq 0.05$; ns= not

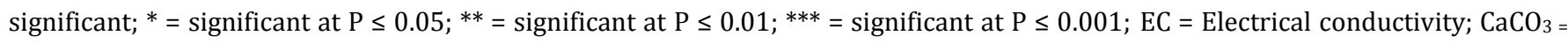
Calcium Carbonate.

Compared with the others adjacent land use types, the lowest mean value of soil reaction was observed under the cultivated land. This might be due to the depletion of basic cations through crop harvesting. Similarly, Bore and Bedadi (2015) also found that the lower soil reaction under cultivated land compared to the adjacent forest and grazing lands.

These results area also in agreement with the results of Takele et al. (2014) who suggested that the soil reaction was lower under cultivated land compared to forest and grazing lands at a soil depth of $0-20 \mathrm{~cm}$ and $20-40 \mathrm{~cm}$. As per rating of soil pH by Tekalign (1991), the soil pH of the study area under grass and forest lands was rated as moderately alkaline whereas the $\mathrm{pH}$ values of cultivated and grazing lands were in the range of slightly alkaline. By and large, the result of high $\mathrm{pH}$ values of soil in the study area was indicated that the presence of calcareous soil, which is characterized by high contents of calcium carbonate $\left(\mathrm{CaCO}_{3}\right)$ compounds, which occupied the exchangeable complex site.

The electrical conductivity $(E C)$ values of soils were significantly $(P \leq 0.01)$ affected by land use types, but not significantly affected by the soil depths and their interaction (Tables 3 and 5). Considering the main effects of land use types, the highest $\left(0.53 \mathrm{dS} \mathrm{m}^{-1}\right)$ and the lowest $\left(0.26 \mathrm{dS} \mathrm{m}^{-1}\right) \mathrm{EC}$ of the soils were obtained in the forest and the grasslands, respectively (Table 5). The lowest EC value under the grassland could be 
associated with the loss of base forming cations through high water percolation since grassland had a low bulk density and higher total porosity.

Similarly, this result is in agreement with findings of Mesele et al. (2006) who found the lower electrical conductivity under grassland compared to the adjacent croplands, bush lands and bushed-grasslands at $0-20$ $\mathrm{cm}$ of soil depth. The EC of soil was going increased with depth i.e. it increased from the surface $(0-20 \mathrm{~cm})$ layer to subsurface $(20-40 \mathrm{~cm})$ layer except in forest land in which it was decreased from surface $[0.57$ $\left.\mathrm{dSm}^{-1}\right)$ to subsurface layer $\left(0.48 \mathrm{dSm}^{-1}\right)$.

According to the standard classification of EC values by Landon (1991), the EC values measured under all land use types in the study area indicated that the concentration of soluble salts is below the levels atwhich growth and productivity of most agricultural crops are affected. This implies that the presence of enough precipitation to evaporation ratio on the study area. Therefore, it is not the limiting factor regarding to plant growth and agricultural crop productivity.

The calcium carbonate $\left(\mathrm{CaCO}_{3}\right)$ of soils was significantly $(\mathrm{P} \leq 0.001)$ affected by land use types and by the interaction of land use types with soil depths, but not significantly affected by the soil depths (Tables 3 and 5). Considering the interaction of land use types by soil depths, the highest (11.50\%) and the lowest (5.10\%) $\mathrm{CaCO}_{3}$ values were observed on the surface $(0-20 \mathrm{~cm})$ soil layer of forest and grazing lands, respectively. According to Landon (1991) classification, the soil classified as none calcareous soil when $\mathrm{CaCO}_{3}$ contents are less than $0.5 \%$ and considered as calcareous soil when it is $0.5 \%$ and above. Based on this classification, the study area was characterized by high content of $\mathrm{CaCO}_{3}$ in all land use types, which indicates that the presence of calcareous soil in the study area. This in turn causes for phosphorous precipitation in the form of Ca-phosphate and ultimately decreases the availability of P in the soil.

\section{Soil organic matter}

The analysis of variance results revealed that the soil OM contents were significantly $(\mathrm{P} \leq 0.001)$ affected by land use types, soil depth and the interaction of land use types with soil depth (Tables 4 and 5). Considering the interaction effects, the highest $(5.60 \%)$ value of soil OM content was recorded on the surface $(0-20 \mathrm{~cm})$ soil layer of forest land and the lowest $(2.73 \%)$ value of soil OM was found under the subsurface $(20-40 \mathrm{~cm})$ soil layer of grazing land (Table 4). The decline of soil OM content in the grazing land might be due to the overgrazing and the heavy compactness of the soil by livestock trampling. This could be in turns hamper an accumulation of soil $\mathrm{OM}$ at both surface and subsurface soil layer. Compared to the grazing lands, cultivated land had relatively higher soil OM at the surface and subsurface soil layer. This could be due to rooting systems in, which grazing lands have fine and short roots while cultivated land has large, and long roots of crops, which can play a great contribution in the enhancement of $\mathrm{OM}$ and soil microorganism function (Gebrelibanos and Assen, 2013).

Table 4. Interaction effects of land use and soil depth on total N, soil OM, C:N and Av. P of the soils on Jila Kerensa kebele

\begin{tabular}{|c|c|c|c|c|c|c|c|c|}
\hline \multirow[b]{3}{*}{ Land use types } & \multirow{2}{*}{\multicolumn{2}{|c|}{$\begin{array}{c}\text { Total N }(\%) \\
\text { Soil depth }(\mathrm{cm}) \\
\end{array}$}} & \multirow{2}{*}{\multicolumn{2}{|c|}{$\begin{array}{c}\text { OM (\%) } \\
\text { Soil depth (cm) }\end{array}$}} & \multirow{2}{*}{\multicolumn{2}{|c|}{$\begin{array}{c}\text { C:N } \\
\text { Soil depth }(\mathrm{cm})\end{array}$}} & \multirow{2}{*}{\multicolumn{2}{|c|}{$\begin{array}{l}\text { Av.P }\left(\mathrm{mg} \mathrm{kg}^{-1}\right) \\
\text { Soil depth }(\mathrm{cm} \\
\end{array}$}} \\
\hline & & & & & & & & \\
\hline & $0-20$ & $20-40$ & $0-20$ & $20-40$ & $0-20$ & $20-40$ & $0-20$ & $20-40$ \\
\hline Grass & $0.26^{\mathrm{ab}}$ & $0.21^{\mathrm{ab}}$ & $4.6^{\mathrm{ab}}$ & $3.60^{\mathrm{b}}$ & $10.5^{b}$ & 10.0 & $2.22^{\mathrm{bc}}$ & $0.88^{\mathrm{b}}$ \\
\hline Cultivated & $0.21^{\mathrm{b}}$ & $0.20^{\mathrm{ab}}$ & $3.7^{b}$ & $3.30^{\mathrm{b}}$ & $10.2^{b}$ & 10.0 & $3.03^{\mathrm{b}}$ & $1.75^{\mathrm{ab}}$ \\
\hline Forest & $0.28^{a}$ & $0.22^{\mathrm{a}}$ & $5.6^{\mathrm{a}}$ & $4.30^{\mathrm{a}}$ & $11.6^{\mathrm{a}}$ & 11.3 & $7.70^{\mathrm{a}}$ & $3.05^{\mathrm{a}}$ \\
\hline Grazing & $0.20^{\mathrm{b}}$ & $0.16^{b}$ & $3.5^{b}$ & $2.73^{b}$ & $10.1^{\mathrm{b}}$ & 9.9 & $1.40^{\mathrm{c}}$ & $1.13^{\mathrm{b}}$ \\
\hline $\mathrm{CV}(\%)$ & 13.31 & 7.83 & 5.90 & 16.47 & 8.77 & 8.81 & 21.86 & 10.33 \\
\hline$P$ - values & *** & $* *$ & $* * *$ & $*$ & $*$ & ns & $* * *$ & $*$ \\
\hline
\end{tabular}

Interaction means within a columns followed by the different letter(s) are significantly different from each other at $\mathrm{P} \leq 0.05$; Av.P = Available phosphorous; $\mathrm{ns}=$ not significant; ${ }^{*}=$ significant at $\mathrm{P} \leq 0.05{ }^{* *}=$ significant at $\mathrm{P} \leq 0.01{ }^{* * *}=\operatorname{significant}$ at $\mathrm{P} \leq 0.001$.

However, the highest value of soil OM on the surface layer of forest land was attributed to the excessive amount of plant residues and biomass on surface land. The soil OM of the study area was going decreased while soil depth was going increased, i.e. the soil OM decreased from the surface $(0-20 \mathrm{~cm})$ to subsurface $(20-40 \mathrm{~cm}$ ) soil layer (Table 4). This implies that the soil OM was suffice on surface soil layer where both animal and plant residues are present to accommodate several diversity of soil organisms. This in turns play vital role in mineralization processes. Therefore, the analysis of variance results confirms that regarding to a soil depth of the study area, the soil OM value was higher $(4.4 \%)$ on the surface soil layer than that of subsurface (3.5\%) soil layer (Table 5). 
This finding is in agreement with different individuals' findings Chibsa and Ta'a (2009), Duguma et al. (2010), Iqbal et al. (2012) and Takele et al. (2014) inwhich they reported that the soil OM decrease with increasing soil depth, with more accumulation on the upper surface soil layer. Similarly, it is in line with the other authors Kiflu and Beyene (2013), in their results they found that soil OM become decreasing with increasing soil depth and it was higher in grassland compared with adjacent maize and enset land at the soil depth of $0-10 \mathrm{~cm}$ and $15-30 \mathrm{~cm}$. This might be due to roots of the grass and fungal hyphae in the grassland soils are probably responsible for the higher amount of soil OM. Generally, based on classification clue cited by Tekalign (1991), soil OM of study area was belonged to medium rate in all land use types except in forest land, which is in the high rate. Soil OM was insignificantly and positively correlated with the soil total porosity, silt and clay at $r=0.40$, at $r=0.29$ and at $r=0.03$, respectively, while it was significantly and positively correlated with the soil total $\mathrm{N}$ and CEC at $\mathrm{r}=0.95^{* * *}$ and at $\mathrm{r}=0.68^{* * *}$, respectively (Table 8). This positive relationship between soil OM and CEC confirm that the more soil OM, the more potential of the nutrient reservoir of the soil and exchangeable basic cations on soil complex site.

\section{Total nitrogen and carbon to nitrogen ratio (C:N)}

The total nitrogen $(\mathrm{N})$ content of soils was significantly ( $\mathrm{P} \leq 0.001)$ affected by land use types. However, it was significantly affected by soil depth at $\mathrm{P} \leq 0.01$ and by the interaction of land use with soil depth at $\mathrm{P} \leq$ 0.05 (Tables 4 and 5). Regarding to the main effects of land use types and soil depths, the average value of total $\mathrm{N}$ was highest $(0.26 \%)$ on the forest land and lowest $(0.18 \%)$ on the grazing land (Table 5 ). The variations of total $\mathrm{N}$ content among different land use types are parallel with that of $\mathrm{OM}$ content, which is decreasing while soil depth was increased (Table 4). The higher total $\mathrm{N}$ content in soils of the forest land could be associated with the high OM contents of the soils, whereas the low content of total $\mathrm{N}$ in grazing land might be due to the house consumption of animal dung as fuel instead of leaving in the field. Further, removal of vegetation by livestock grazing and expose the surface layer of grazing land to direct rain drop could be generating more surface runoff, which can remove the animal and plant residues from the surface soil layer thereby cause for total $\mathrm{N}$ depletion.

Similarly, Nigussie and Kissi (2012), Ufot et al. (2016) and Chemada et al. (2017) stated that the higher total $\mathrm{N}$ was obtained under forest land compared to the adjacent grazing and cultivated lands. Regarding to the interaction of land use types with the soil depths, the highest $(0.28 \%)$ total $\mathrm{N}$ was recorded on the surface $(0-20 \mathrm{~cm})$ soil layer of forest land while the lowest $(0.16 \%)$ total $\mathrm{N}$ was recorded at the subsurface $(20-40$ $\mathrm{cm}$ ) soil layer of grazing land (Table 4). According to the rating of total $\mathrm{N}$ by Tekalign (1991), the total $\mathrm{N}$ in the study area was in a medium rate under grazing and cultivated lands while it was rated as high in the grass and forest lands.

Table 5. Main effect of land use types and soil depth on selected chemical properties of soil on Jila Kerensa kebele

\begin{tabular}{|c|c|c|c|c|c|c|c|}
\hline Treatments & $\begin{array}{l}\mathrm{pH}-\mathrm{H}_{2} \mathrm{O} \\
(1: 2.5)\end{array}$ & $\begin{array}{l}\mathrm{EC} \\
\left(\mathrm{dS} \mathrm{m}^{-1}\right)\end{array}$ & $\begin{array}{l}\mathrm{CaCO}_{3} \\
(\%) \\
\end{array}$ & $\begin{array}{l}\text { Total N } \\
(\%)\end{array}$ & $\begin{array}{l}\mathrm{OM} \\
(\%)\end{array}$ & $\mathrm{C}: \mathrm{N}$ & $\begin{array}{l}\text { Av. P } \\
\left(\mathrm{mg} \mathrm{kg}^{-1}\right)\end{array}$ \\
\hline & & & \multicolumn{5}{|c|}{ Land use types } \\
\hline Grass & 8.00 & $0.26^{b}$ & $8.73^{b}$ & $0.24^{b}$ & $4.12^{\mathrm{b}}$ & $10.30^{\mathrm{b}}$ & $1.55^{\mathrm{bc}}$ \\
\hline Cultivated & 7.68 & $0.32^{b}$ & $7.00^{c}$ & $0.21^{\mathrm{b}}$ & $3.51^{b}$ & $10.10^{\mathrm{b}}$ & $2.40^{\mathrm{b}}$ \\
\hline Forest & 7.90 & $0.53^{\mathrm{a}}$ & $10.45^{\mathrm{a}}$ & $0.26^{\mathrm{a}}$ & $5.02^{\mathrm{a}}$ & $11.50^{\mathrm{a}}$ & $5.37^{\mathrm{a}}$ \\
\hline \multirow[t]{2}{*}{ Grazing } & 7.70 & $0.36^{b}$ & $5.36^{\mathrm{d}}$ & $0.18^{b}$ & $3.15^{b}$ & $10.00^{\mathrm{b}}$ & $1.26^{c}$ \\
\hline & & & \multicolumn{5}{|c|}{ Soil depth $(\mathrm{cm})$} \\
\hline $0-20$ & 7.82 & 0.38 & 7.80 & $0.24^{\mathrm{a}}$ & $4.4^{\mathrm{a}}$ & 10.5 & $3.58^{\mathrm{a}}$ \\
\hline $20-40$ & 7.81 & 0.36 & 7.96 & $0.20^{\mathrm{b}}$ & $3.5^{b}$ & 10.3 & $1.71^{\mathrm{b}}$ \\
\hline Land use & ns & $* *$ & $* * *$ & $* * *$ & $* * *$ & $*$ & $* * *$ \\
\hline Depth & ns & ns & ns & $* *$ & $* *$ & ns & $* * *$ \\
\hline Land use * depth & ns & ns & $* * *$ & $* *$ & $* *$ & ns & $* * *$ \\
\hline $\mathrm{CV}(\%)$ & 4.22 & 21.30 & 4.95 & 9.47 & 10.03 & 8.73 & 28.10 \\
\hline
\end{tabular}

Main effect means within a columns followed by the different letter(s) are significantly different from each other at $\mathrm{P} \leq 0.05$; ns= not significant; ${ }^{*}=$ significant at $\mathrm{P} \leq 0.05$; ${ }^{* *}=$ significant at $\mathrm{P} \leq 0.01 ;{ }^{* *}=$ significant at $\mathrm{P} \leq 0.001$.

According to the analysis of variance results indicated that the carbon to nitrogen ratio (C:N) of the soils in study area was significantly ( $\mathrm{P} \leq 0.05)$ affected by land use types. However, it was not significantly affected by soil depth and the interaction effects (Tables 4 and 5). Considering the main effects of soil depth, the higher (10.5) mean value of C:N was found on the surface $(0-20 \mathrm{~cm})$ soil layer. This indicates that the rate at, which total $\mathrm{N}$ decreased with soil depth was much higher than the reduction in carbon. 
In fact, the $\mathrm{C}: \mathrm{N}$ of the soil is decreasing while the soil depth going increase. Occasionally it can increase with the increment of soil depth in some exceptional cases, which might be due the alluvial soil that contain more $\mathrm{C}: \mathrm{N}$ in subsurface soil layer than surface soil layer through sedimentation processes. However, the finding of this study was indicated the $\mathrm{C}: \mathrm{N}$ was decreased when the soil depth increased. Considering the interaction effects, the highest (11.6) and the lowest (9.9) C:N values were recorded at the surface soil layers of the forest and grazing lands, respectively (Table 4). The higher C: $\mathrm{N}$ in forest soil indicates the prevalence of optimum biological activities, whereas the lower $\mathrm{C}: \mathrm{N}$ in the surface soil of grazing and cultivated lands might be due to higher microbial activity and more $\mathrm{CO}_{2}$ evolution and its loss to the atmosphere at the surface (0$20 \mathrm{~cm}$ ) soil layer than in the subsurface $(20-40 \mathrm{~cm})$ soil layer.

The current result is in agreement with the findings of Gebrelibanos and Assen (2013) who found that the higher $\mathrm{C}: \mathrm{N}$ in forest land compared to the adjacent plantation, grazing and cultivated lands. Additionally, Selassie and Ayanna (2013) found that the higher C:N in natural forest than the adjacent eucalyptus plantation, grazing and cultivated lands. They also suggested that the optimum range of the C:N is about 10:1 to 12:1 that provides nitrogen in excess of microbial activities. Accordingly, the C:N of the soil across the land use types under the study area were considered to be within the optimum range in all land use types. This indicates that the presence of suitable mineralization processes of soil organisms.

The soil total $\mathrm{N}$ and C: $\mathrm{N}$ were insignificantly and negatively correlated with the soil bulk density at $\mathrm{r}=-0.38$ and $r=-0.28$, respectively. The soil total $\mathrm{N}$ was significantly and positively $\left(r=0.92^{* * *}\right)$ correlated with the availability P. Similarly, the C: $\mathrm{N}$ was significantly and positively $\left(\mathrm{r}=0.66^{* * *}\right)$ correlated with the soil OM (Table 8).

\section{Available phosphorus}

According the analysis of variance results indicated that the available $\mathrm{P}$ of the study area was significantly (P $\leq 0.001$ ) affected by land use types, soil depth and the interaction of land use type with soil depth (Tables 4 and 5). The available $P$ was higher in the surface soil layer than in the subsurface soil layer (Table 5). Generally, variations in available P contents in soils could be related to the intensity of soil weathering or soil disturbance under different land use types. Considering the main effects of land use types, the highest (5.37 mg kg-1) available P was recorded on the forest land and the lowest $\left(1.26 \mathrm{mg} \mathrm{kg}^{-1}\right)$ was recorded on the grazing land (Table 5).

Considering the interaction effect of land use types with soil depth, the highest $\left(7.70 \mathrm{mg} \mathrm{kg}^{-1}\right)$ and the lowest (1.13 $\mathrm{mg} \mathrm{kg}^{-1}$ ) of available P contents was recorded at the surface soil layer of the forest and subsurface soil layer of the grazing lands, respectively (Table 4). Although Aytenew and Kibret (2016) and Chemada et al. (2017) reported that the higher available P was recorded in cultivated land than the adjacent grazing and forest lands, this finding reported that the higher available $\mathrm{P}$ was obtained in forest land at both surface and subsurface soil layer.

Relatively the high content of available $\mathrm{P}$ in the forest land could be due to the high content of soil OM resulting in the release of organic phosphorus thereby enhances available P under forest land. Similarly, this result is in agreement with the findings of Abad et al. (2014) who reported that the available P was high in forest land compared to pasture land and cultivated land at $0-30 \mathrm{~cm}$ soil depth. Additionally, it is in line with result of Takele et al. (2014) whose results revealed that available P was high in forest land than the adjacent cultivated and grazing lands at a soil depth of 0-10 cm, 10-20 cm and 20-30 cm. Compared with the rest of land use types in the study area, the higher available $\mathrm{P}$ was also recorded in the cultivated land next to the forest land. This might be due to the application of diammonium phosphate (DAP) and nitrogen phosphorous sulfur (NPS) fertilizers on the cultivated lands of the study area.

As per the ratings of available $\mathrm{P}$ by Olsen et al. (1954), the available P of the soil under this study was rated as very low in the grass, cultivated and grazing lands whereas it was rated as low in forest land. This deficiency of available $\mathrm{P}$ on the study area could be due to the high $\mathrm{CaCO}_{3}$ content of the soil since the available P can precipitate in the form of calcium phosphate in calcareous soil. Similarly, Melese et al. (2015) reported that in calcareous soil, the available $\mathrm{P}$ was low due to the precipitation of $\mathrm{P}$ in the form of calcium phosphate.

\section{Cation exchange capacity}

The analysis of variance results revealed that the cation exchange capacity (CEC) of the soils in the study area was significantly $(\mathrm{P} \leq 0.05)$ affected by the land use types. The CEC means values under grass, cultivated, forest and grazing lands were 38.5, 33.2, 41.7 and, $30.1 \mathrm{cmol}_{\mathrm{c}} \mathrm{kg}^{-1}$, respectively (Table 7). The higher and lower of CEC in forest and grazing land might be due to the presence and absence of soil organic 
matter or high soil organic matter in forest land while it was less in grazing land. Besides, the amount and types of clay particles also the determinant factor on the CEC of soil under different land use types.

Table 6. Interaction effects of land use types and soil depth on Na, K, Mg, Ca, CEC and PBS on Jila Kerensa kebele

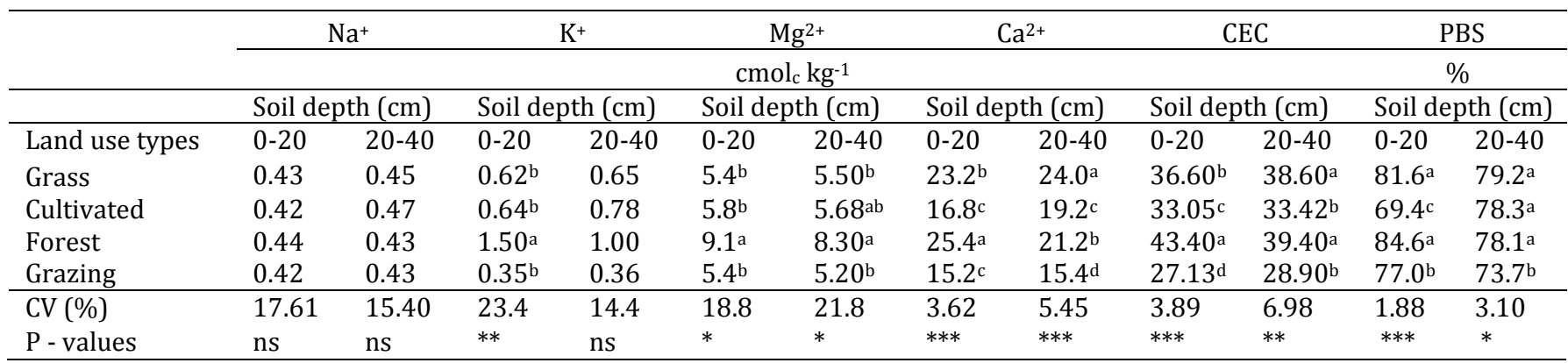

Interaction means within a columns followed by the different letter(s) are significantly different from each other at $\mathrm{P} \leq 0.05$; ns $=$ not significant; * = significant at $\mathrm{P} \leq 0.05 ;^{* *}=$ significant at $\mathrm{P} \leq 0.01 ;^{* * *}=$ significant at $\mathrm{P} \leq 0.001$.

This result is in agreement with the findings of Yitbarek et al. (2013) who suggested that the CEC of soil was higher in forest land compared to that of the adjacent grazing and cultivated lands. Considering the interaction effects, the CEC of the soil under the study area was significantly $(P<0.05)$ affected by interaction of land use types with the soil depth (Table 6). The highest (43.40 $\left.\mathrm{cmol}_{\mathrm{c}} \mathrm{kg}^{-1}\right)$ value of CEC was recorded on the surface $(0-20 \mathrm{~cm})$ soil layer of forest land, whereas the lowest $\left(27.13 \mathrm{cmol}_{\mathrm{c}} \mathrm{kg}^{-1}\right)$ was recorded at the surface soil layer of grazing land. Considering the soil depth, like that of the interaction of land use types with soil depth, the CEC values of the soil under different land use types were not significantly affected by soil depth. But numerically, the higher CEC value was found in the subsurface $(20-40 \mathrm{~cm})$ soil layer (Table 7). Similarly, Kiflu and Beyene (2013) reported that the CEC of the soil was not significantly affected by soil depth at a soil depth of 0-15 cm and 15-30 cm under adjacent maize, enset and grasslands.

Moreover, Nigussie and Kissi (2012) reported that the CEC of soil was higher in the subsurface of soil layer under the adjacent forest, cultivated and grazing lands. As per the ratings CEC recommended by Hazelton and Murphy (2007), the CEC value of soil under the grass, cultivated and grazing land were in the range of high rate while it was rated as very high under the forest land. The CEC of the soil was significantly and positively correlated with the total porosity $\left(\mathrm{r}=0.75^{* * *}\right), \mathrm{CaCO}_{3}\left(\mathrm{r}=0.93^{* * *}\right)$, total $\mathrm{N}\left(\mathrm{r}=0.67^{* * *}\right)$, soil $\mathrm{OM}(\mathrm{r}$ $\left.=0.68^{* * *}\right)$, available P $\left(\mathrm{r}=0.63^{* * *}\right)$ and PBS $\left(\mathrm{r}=0.61^{* *}\right)($ Table 8$)$.

\section{Exchangeable bases}

The analysis of variance results indicated that the exchangeable Ca was significantly ( $\mathrm{P} \leq 0.001)$ affected by land use types, soil depths and the interaction of land use types with soil depth (Tables 6 and 7).The presence of such significant variation on exchangeable Ca could be triggered from different management practice, way of land utility, and the various imbalances proportional of soil texture and OM. Considering the main effect of land use types, the mean values of exchangeable Ca under grass, cultivated, forest and grazing lands were 23.6, 17.7, 24.1 and $16.2 \mathrm{cmol}_{\mathrm{c}} \mathrm{kg}^{-1}$, respectively (Table 7).

Table 7. Main effects of land use types and soil depth on selected chemical properties of soil on Jila Kerensa kebele

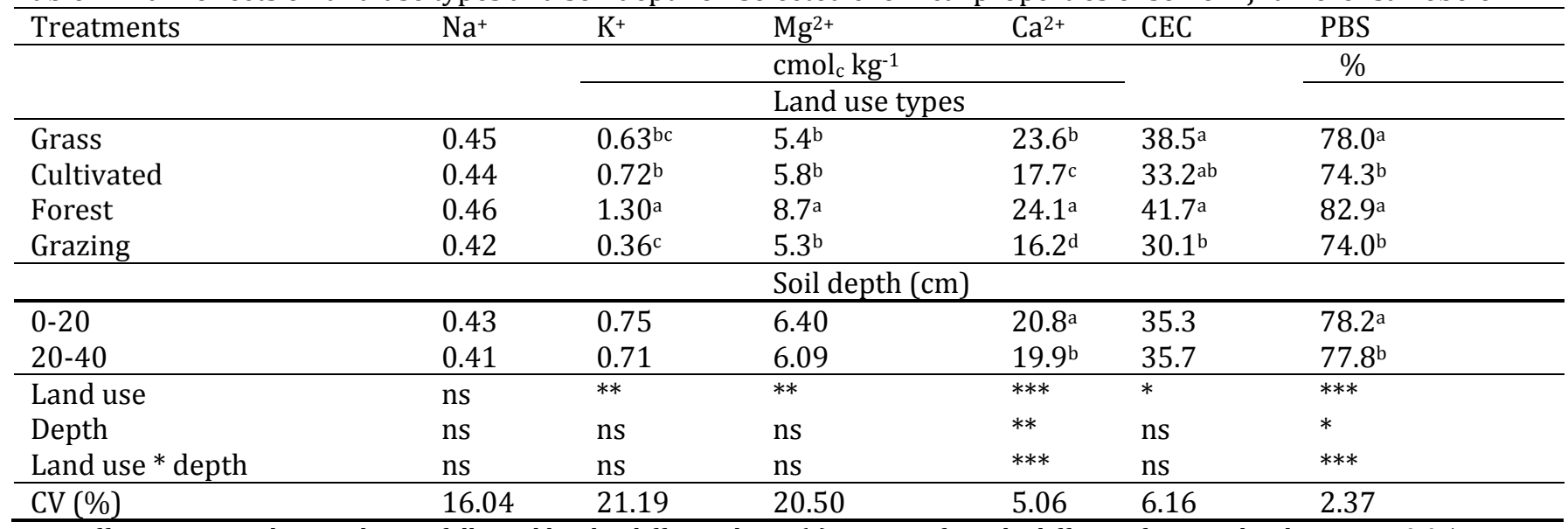

Main effect means within a columns followed by the different letter(s) are significantly different from each other at $\mathrm{P} \leq 0.05$; ns = not significant; ${ }^{*}=$ significant at $\mathrm{P} \leq 0.05 ;{ }^{* *}=$ significant at $\mathrm{P} \leq 0.01$; $^{* * *}=$ significant at $\mathrm{P} \leq 0.001$.

Regarding to exchangeable $\mathrm{Ca}$ at both soil depths, the exchangeable Ca was higher at the surface soil depth than at the subsurface soil depth (Table 7). This could be the possibility of the high exchangeable Ca was 
available on surface soil layer with an abundance of animal and plant residues than beneath the soil layer. This is parallel with the work of Kiflu and Beyene (2013) in their results, they revealed that the exchangeable Ca contents of soil was higher on the surface soil layer than the subsurface soil layer due to the association of biological accumulation with biological activity and accumulation from plant residues.

However, Bore and Bedadi (2015) reported that the exchangeable Ca was increasing with increasing soil depth since it is susceptible and possibility of easily leach downward by runoff and water percolation. In terms of the interaction of land use types with the soil depth, the highest $\left(25.4 \mathrm{cmol}_{c} \mathrm{~kg}^{-1}\right)$ and the lowest (15.2 $\mathrm{cmol}_{\mathrm{c}} \mathrm{kg}^{-1}$ ) exchangeable Ca was found in the surface soil layer of the forest and grazing lands, respectively (Table 6). As per the ratings of FAO (2006), the exchangeable Ca contents of study area soil was categorized as high rate under cultivated and grazing lands whereas categorized as very high rate under grass and forest lands. Therefore, by standing on this view of point, the study area was characterized by high contents of exchangeable Ca.

The analysis of variance result indicated the exchangeable $\mathrm{Mg}$ was significantly $(\mathrm{P} \leq 0.001)$ affected by land use types while it was not significantly affected by soil depths and the interaction effects (Tables 6 and 7). Considering the main effect of land use types, the mean values of exchangeable Mg under grass, cultivated, forest and grazing lands were 5.4, 5.8, 8.7 and, $5.3 \mathrm{cmol}_{\mathrm{c}} \mathrm{kg}^{-1}$, respectively (Table 7). Considering the interaction effects, the highest $\left(9.1 \mathrm{cmol}_{\mathrm{c}} \mathrm{kg}^{-1}\right)$ exchangeable $\mathrm{Mg}$ was recorded on the surface soil layer of forest land while the lowest $\left(5.2 \mathrm{cmol}_{\mathrm{c}} \mathrm{kg}^{-1}\right)$ exchangeable $\mathrm{Mg}$ was obtained under the subsurface soil layer of grazing land (Table 6). As per the ratings of FAO (2006), the exchangeable Mg contents of the study area under grass, cultivated and grazing lands were in the range of high rate, whereas the exchangeable $\mathrm{Mg}$ contents under forest land was in the range of very high rate. The ratios of exchangeable Ca to $\mathrm{Mg}$ were within the critical values (3:1 to 5:1), which may not cause of the nutrient imbalance under different land use types of the study area.

The exchangeable $\mathrm{K}$ of soil under study area was significantly $(\mathrm{P} \leq 0.001)$ affected by land use types. But it was not significantly affected by soil depths and the interaction of land use types with soil depth (Tables 6 and 7). Concerning to the main effect of land use types, the mean values of exchangeable $\mathrm{K}$ under grass, cultivated, forest and grazing lands were $0.63,0.72,1.30$ and $0.36 \mathrm{cmol}_{\mathrm{c}} \mathrm{kg}^{-1}$, respectively (Table 7). Considering the soil depths of the study area, the higher exchangeable K was found on the surface $(0-20 \mathrm{~cm})$ soil layer (Table 7).

Considering the interaction effects, the highest $\left(1.50 \mathrm{cmol}_{\mathrm{c}} \mathrm{kg}^{-1}\right)$ and the lowest $\left(0.35 \mathrm{cmol}_{\mathrm{c}} \mathrm{kg}^{-1}\right)$ values of exchangeable $\mathrm{K}$ contents was recorded on the surface soil layer of forest and grazing lands, respectively (Table 6). The higher exchangeable $\mathrm{K}$ on the surface layer of forest land could be due to the availability of surface biomass through litter falling and little or no surface soil disturbance by rain drops, surface runoff and other severe erosion agents. The derivative of this phenomenon is the reasonable for lower exchangeable $\mathrm{K}$ in case of surface layer of grazing land in, which higher disturbance was severe and exacerbate soil erosion.

Similarly, this result is in agreement with the work of Yitbarek et al. (2013) and Duguma et al. (2014) whose findings was reported that the exchangeable $\mathrm{K}$ of soil is higher in the forest land than cultivated and grazing lands. According to the rate of exchangeable K cited by FAO (2006), the exchangeable K contents of grass and cultivated lands of the study area were rated as high, whereas that of grazing and forest lands were rated as medium and very high, respectively.

The analysis of variance results indicated the exchangeable $\mathrm{Na}$ of the study area was not significantly affected by land use types, soil depth and interaction of land use types with the soil depth (Tables 6 and 7). This finding is in agreement with that of Gebrelibanos and Assen (2013) who reported that, the exchangeable $\mathrm{Na}$ is not indicated the significant variation, neither under land use types nor across the soil depth by the time exchangeable $\mathrm{Ca}, \mathrm{Mg}$ and $\mathrm{K}$ was showing significant variation under adjacent different land use types.

However, Selassie and Ayanna (2013), Aytenew and Kibret (2016) and Ufot et al. (2016) reported that like that of exchangeable $\mathrm{Ca}, \mathrm{Mg}$ and $\mathrm{K}$, exchangeable $\mathrm{Na}$ also affected by land use types. Although there was no statistical variation on exchangeable $\mathrm{Na}$ of the study area, more or less the numerical variation was remarkable on exchangeable Na under different land use types and on the interaction effects. Considering the mean values of exchangeable $\mathrm{Na}$ of the study area, $0.45,0.44,0.46$ and $0.42 \mathrm{cmol}_{\mathrm{c}} \mathrm{kg}^{-1}$ were found under grass, cultivated, forest and grazing lands, respectively. The higher exchangeable Na was observed on the surface $(0-20 \mathrm{~cm})$ soil layer than the subsurface $(20-40 \mathrm{~cm})$ soil layer (Table 7). 


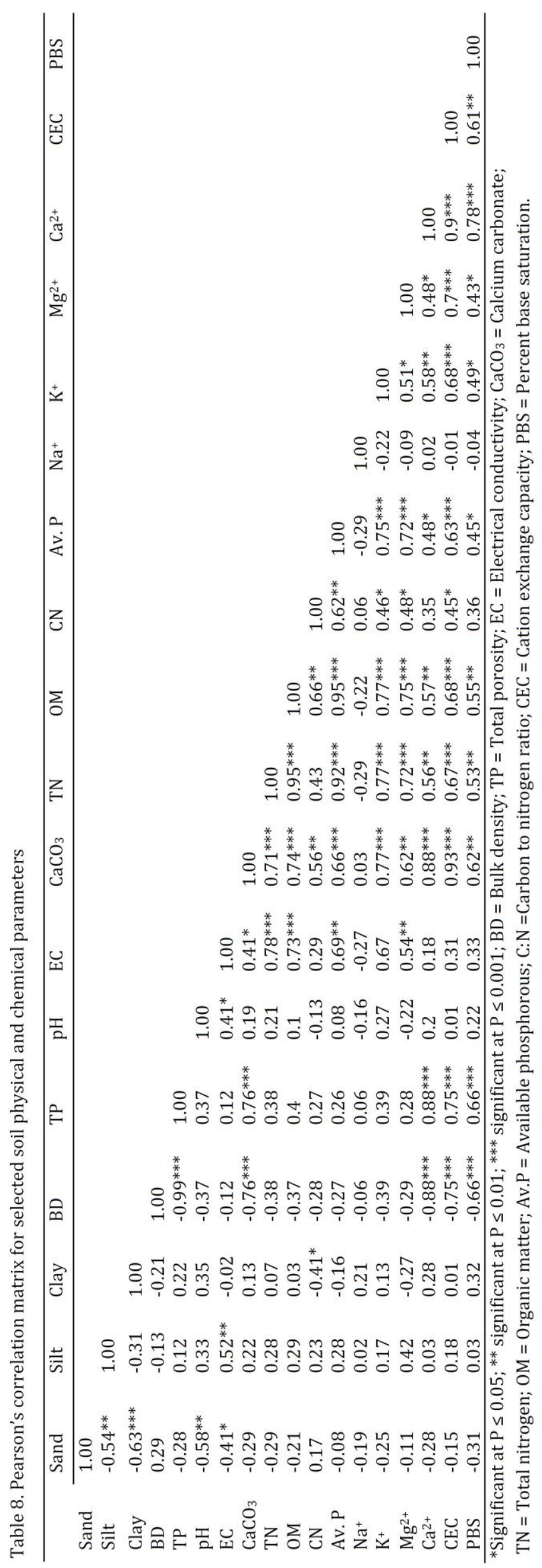


Considering to the interaction of land use types with soil depth, the highest $\left(0.47 \mathrm{cmol}_{\mathrm{c}} \mathrm{kg}^{-1}\right)$ exchangeable $\mathrm{Na}$ was obtained under the subsurface soil layer of forest land, whereas the lowest $\left(0.42 \mathrm{cmol}_{\mathrm{c}} \mathrm{kg}^{-1}\right)$ exchangeable $\mathrm{Na}$ was obtained on the surface soil layer of both cultivated and grazing lands (Table 6). Though there was no statistical variation in its values, the higher exchangeable $\mathrm{Na}$ in the forest land might be due to the availability and accumulation of plant residues resulted from an abscissions of leaf trees and biological functions thereby enhance exchangeable $\mathrm{Na}$ in forest land. On the other hand, the lower exchangeable $\mathrm{Na}$ in cultivated and grazing lands attributed to the removal of crops residues on cultivated land through harvesting activities, whereas the removal of surface vegetation by livestock grazing may render the lower exchangeable Na on grazing land.

This result is also parallel with the results of Chemada et al. (2017) who found that the lower exchangeable $\mathrm{Na}$ under cultivated and grazing lands compared to the adjacent forest land. As per rating of FAO (2006), the exchangeable $\mathrm{Na}$ of the study area was in the range of medium rate under all land use types. Therefore, the exchangeable $\mathrm{Na}$ of soil under this study was not the limiting factor on crop productivity and not surplus that may trigger soil sodicity, which in turns hamper the agricultural practices.

\section{Percent base saturation}

The percent base saturation (PBS) of the study area was significantly ( $\mathrm{P} \leq 0.05$ ) affected by land use types and interaction of land use types with soil depth (Tables 6 and 7). Considering the interaction of land use types with soil depth, the highest (84.6\%) and the lowest (69.4\%) value of PBS was obtained in the surface $(0-20 \mathrm{~cm})$ soil layer of forest land and grazing land, respectively (Table 6).

Considering the main effects of land use types, the highest (82.9\%) and the lowest (74.0\%) values of PBS were recorded under the forest and grazing lands, respectively (Table 7). In general, processes that affect the extent of basic cations also affect percent base saturation of the soil. According to the rate of PBS cited by Hazelton and Murphy (2007), the PBS of the study area was rated as high in the grass, cultivated and grazing lands whereas it was rated as very high in the forest land. This implies that the soil under the study area was contained high exchangeable bases.

\section{Conclusion}

The objective of the this study was to evaluate the selected soil physical and chemical properties as affected by different land use types on Kuyu district, north Shewa zone, Central Highland of Ethiopia. The study area has low bulk density, which is indicating the higher soil $\mathrm{OM}$ and clay soil particles. The soil pH ranged in between 7.68 to 8.00 in cultivated and forest lands, respectively. The highest mean value EC ranged in between 0.53 to $0.26 \mathrm{dSm}^{-1}$.

The higher soil $\mathrm{OM}$ and total $\mathrm{N}$ were recorded in the forest land while the lower was found in the grazing land. Considering the main effect of soil depths, the higher soil OM was observed on the surface soil layer and it is decreasing with increasing soil depth. The average values of exchangeable basic cations (Ca, $\mathrm{Mg}, \mathrm{K}$ and $\mathrm{Na}$ ) ranged from 12.6 to $24.1,5.3$ to $8.7,0.36$ to 1.3 and 0.42 to $0.46 \mathrm{cmol}_{\mathrm{c}} \mathrm{kg}^{-1}$ in grazing and forest land, respectively. The CEC of soil under the study area was categorized in the high rate in grass, grazing and cultivated lands, whereas rated as very high in forest land. The mean values of PBS ranged between 74.0 to $82.9 \%$ in grazing and forest lands, respectively.

Generally, the study area has high $\mathrm{pH}$, clay particles, total porosity, exchangeable basic cations, CEC and $\mathrm{CaCO}_{3}$, but has low available $\mathrm{P}$. The available $\mathrm{P}$ was the limited nutrient in the study area, which might be due to its fixation by $\mathrm{CaCO}_{3}$. Therefore, the supply of high $\mathrm{P}$ fertilizers levels are important, which can increase crop productivity. To minimize the $\mathrm{P}$ fixation and increase its availability, band or localized application of $\mathrm{P}$ fertilizer is highly recommended in the study area.

\section{References}

Abad, J.R.S., Hassan, K., Alamdarlou, E.H., 2014. Assessment the effects of land use changes on soil physicochemical properties in Jafarabad of Golestan province, Iran. Bulletin of Environment, Pharmacology and Life Sciences 3: 296-300.

Abbasi, M.K, Zafar, M., Khan, S.R., 2007. Influence of different land-cover types on the changes of selected soil properties in the mountain region of Rawalakot Azad Jammu and Kashmir. Nutrient Cycling in Agroecosystems 78(1): 97110.

Adeyemo, A.J., Agele, S.O., 2010. Effects of tillage and manure application on soil physicochemical properties and yield of maize grown on a degraded intensively tilled alfisol in southwestern Nigeria. Journal of Soil Science and Environmental Management 1(8): 205-216. 
Aytenew, M., Kibret, K., 2016. Assessment of soil fertility status at dawja watershed in Enebse Sar Midir district, Northwestern Ethiopia. International Journal of Plant \& Soil Science 11(2): 1-13.

Black, C.A., 1965. Methods of soil analysis. Part 1 Physical and mineralogical properties, American Society of Agronomy, No:9. Madison, WI, USA.

Bore, G., Bedadi, B., 2015. Impacts of land use types on selected soil physico-chemical properties of Loma Woreda, Dawuro Zone, Southern Ethiopia. Science, Technology and Arts Research Journal 4(4): 40-48.

Bouyoucos, G.J., 1962. Hydrometer method improved for making particle size analysis of soils. Agronomy Journal 54(5): 464-465.

Chapman, H.D., 1965. Cation exchange capacity. In: Methods of Soil Analysis. Part II, Black, C.A. (Ed.). Agronomy No. 9. American Society of Agronomy, Madison, Wisconsin, USA. pp. 891-901.

Chemada, M., Kibret, K., Fite, T., 2017. Influence of different land use types and soil depths on selected soil properties related to soil fertility in Warandhab Area, Horo Guduru Wallaga Zone, Oromiya, Ethiopia. International Journal of Environmental Sciences and Natural Resources 4 (2): 555634.

Chibsa, T., Ta'a, A., 2009. Assessment of soil organic matter under four land use systems in Bale Highlands, Southeast Ethiopia A. Soil organic matter contents in four land use systems: forestland, grassland, fallow land and cultivated land. World Applied Sciences Journal 6(9): 1231-1246.

Duguma, L.A., Hager, H., Sieghardt, M., 2010. Effects of Land use types on soil chemical properties in small holder farmers of Central Highland Ethiopia. Ekológia (Bratislava) 29(1): 1-14.

FA0, 1998. Top soil characterization for sustainable land management. (DRAFT). Food and Agriculture Organization, Land and Water Development Division, Soil Resources, Management and Conservation Service, Rome, Italy. Available at: [access date: 18.05.2018]: https://library.wur.nl/isric/fulltext/isricu_i14388_001.pdf

FAO, 2006. Plant Nutrition for Food Security: A guide for integrated nutrient management. FAO Fertilizer and Plant Nutrition Bulletin No. 16, Food and Agriculture Organization, Rome, Italy. Available at: [access date: 18.05.2018]: http://www.fao.org/fileadmin/templates/soilbiodiversity/Downloadable_files/fpnb16.pdf

FAO/UNDP, 1984. Provisional soils association map of Ethiopia (1:2,000,000). Assistance to land use planning. Food and Agriculture Organization/United Nations Development Program. Addis Ababa, Ethiopia. 29p.

Gebrelibanos, T., Assen, M., 2013. Effects of land-use/cover changes on soil properties in a dry land watershed of Hirmi and its adjacent agro ecosystem: Northern Ethiopia. International Journal of Geosciences Research 1(1): 45-57.

Hazelton, P., Murphy, B., 2007. Interpreting soil test results: What do all the numbers mean? CSIRO Publishing. Australia, 52p.

Iqbal, M., Khan, A.G., Hassan, A.U., Amjad, M., 2012. Soil physical health indices, soil organic carbon, nitrate contents and wheat growth as influenced by irrigation and nitrogen rates. International Journal of Agriculture and Biology 14: 20-28.

Kiflu, A., Beyene, S., 2013. Effects of different land use systems on selected soil properties in South Ethiopia. Journal of Soil Science and Environment Management 4(5): 100-107.

KWAO (Kuyu Woreda Agricultural Office), 2017. Annual reported data on land use systems. Unpublished document. Gerba Guracha, Ethiopia.

Landon, J., 1991. Booker tropical soil manual: A handbook for soil survey and agricultural land evaluation in the tropics and subtropics. John Wiley \& Sons. Inc. New York, USA. 530p.

Lelisa, A., Abebaw, A., 2016. Study on selected soll physicochemical properties of rehabilitated degraded bare land: The case of Jigessa rehabilitation site, Borana zone, Ethiopia. Global Journal of Advanced Research 3(5): $345-354$.

Lemenih, M., Karltun, E., Olsson, M., 2005. Assessing soil chemical and physical property responses to deforestation and subsequent cultivation in smallholders farming system in Ethiopia. Agriculture, Ecosystem and Environment 105(1-2): 373-386.

Lemma, B., Kleja, B.D., Nilsson, I., Olsson, M., 2006. Soil carbon sequestration under different exotic tree species in the southwestern highlands of Ethiopia. Geoderma 136(3-4): 886-898.

Liu, X.L., He, Y.Q., Zhang, H.L., Schroder, J.K., Li, C.L., Zhou, J., Zhang, Z.Y., 2010. Impact of land use and soil fertility on distributions of soil aggregate fractions and some nutrients. Pedosphere 20(5): 666-673.

Melese, A., Gebrekidan, H., Yli-Halla, M., Yitaferu, B., 2015. Phosphorus status, inorganic phosphorus forms, and other physicochemical properties of acid soils of Farta District, Northwestern Highlands of Ethiopia. Applied and Environmental Soil Science Article ID 748390.

Mesele, S., Gebrekidan, H., Gizachew, L., Layne, C., 2006. Changes in land cover and soil conditions for the Yabelo district of the Borana plateau, 1973-2003. Global Livestock Collaborative Research Support Program. University of California, Davis. 4p.

Mustapha, S. 2007. Physico-chemical properties and fertility status of some Haplic Plinthaquults in Bauchi local government area of Bauchi State, Nigeria. International Journal of Soil Science 2(4): 314-315.

Nigussie, A., Kissi, E., 2012. Physicochemical characterization of nitisol in Southwestern Ethiopia and its fertilizer recommendation using NuMaSS. Global Advanced Research Journal of Agricultural Science 1(4): 66-73.

Olsen, S.R., Watenabe, V.C., Dean, L.A., 1954. Estimate of available phosphorous in soil by extraction with sodium bicarbonate. USDA Circular. No. 939, USA. 
Pavlů, L., Borůvka, L., Nikodem, A., Rohošková, M., Penížek, V., 2007. Altitude andforest types effects on soils in Jizera mountain regions. Soil and Water Research 2(2): 35-44.

Qadir, M., Quillérou, E., Nangia, V., Murtaza, G., Singh, M., Thomas, R.J., Drechsel, P., Noble, A.D., 2014. Economics of saltinduced land degradation and restoration. Natural Resources Forum, A United Nations Sustainable Development Journal 38(4): 282-295.

Rowell, D., 1994. Soil science: Methods and applications. Longman Limited. England. 350p.

SAS (Statistical Analysis System), 2013. SAS Institute Inc. SAS/STAT 9.4 User's guide. Cary, NC, SAS Institute, USA, 2008.

Selassie, Y.G., Ayanna, G., 2013. Effects of different land use systems on selected physico-chemical properties of soils in Northwestern Ethiopia. Journal of Agricultural Science 5(4): 112-120.

Takele, L., Chimdi, A., Abebaw, A., 2014. Dynamics of Soil fertility as influenced by different land use systems and soil depth in West Showa Zone, Gindeberet District, Ethiopia. Agriculture, Forestry and Fisheries 3(6): 489-494.

Tekalign, T., 1991. Soil, plant, water, fertilizer, animal manure and compost analysis. Working Document No. 13. International Livestock Research Center for Africa (ILCA), Addis Ababa, Ethiopia.

Ufot, U.O., Iren, O.B., Chikere Njoku, C.U., 2016. Effects of land use on soil physical and chemical properties in Akokwa area of Imo State, Nigeria. International Journal of Life Sciences Scientific Research 2(3): 273-278.

USDA, 2008. Bulk density. United States Department of Agriculture (USDA), Natural Resources Conservation Service. Available at [Access date: 17.05.2018]: https://www.nrcs.usda.gov/wps/PA_NRCSConsumption/download?cid=nrcs142p2_051591\&ext=pdf

Van-Reeuwijk, L., 1992. Procedures for Soil Analysis (3rd ed.), International Soil Reference and Information Center (ISRIC). Wageningen. The Netherlands.

Walkley, A., Black, I.A., 1934. An examination of Degtjareff method for determining soil organic matter and a proposed modification of the chromic acid titration method. Soil Science 37(1):29-37.

Yimer, F., Abdulkadir, A., 2011. The effect of cropland fallowing on soil nutrient restoration in the Bale Mountains, Ethiopia. Journal of Science and Development 1(1): 43-51.

Yimer, F., Ledin, S., Abdulakdir, A., 2008. Concentrations of exchangeable bases and cation exchange capacity in soils of cropland, grazing and forest in the Bale Mountains, Ethiopia. Forest Ecology and Management 256(6): 12981302 .

Yitbarek, T., Gebrekidan, H., Kibret, K., Beyene, S., 2013. Impacts of Land Use on Selected Physicochemical Properties of Soils of Abobo Area, Western Ethiopia. Agriculture, Forestry and Fisheries 2(5): 177-183. 